\title{
Drug Class Measurement
}

National Cancer Institute

\section{Source}

National Cancer Institute. Drug Class Measurement. NCI Thesaurus. Code C74675.

The determination of the levels of all members of a specific drug class present in a sample. 